\title{
Perancangan Tableware dengan Material Olahan Bonggol Jagung
}

\author{
Zahra Annisa Evrianda dan Dedy Ismail \\ Jurusan Desain Produk, Fakultas Seni Rupa dan Desain, ITENAS, Bandung \\ e-mail : zahraaev2112@gmail.com
}

\begin{abstract}
Abstrak-Material olahan bonggol jagung berbentuk balok memiliki karakteristik yang dapat dijadikan potensi sebagai bahan baku non-konvensional untuk pembuatan produk fungsional. Penelitian yang dilakukan ini bertujuan untuk mengetahui potensi lebih lanjut dari modul bonggol jagung berbentuk balok yang dapat diterapkan sebagai fungsi dari tableware. Adapun cara untuk mengetahuinya adalah dengan melakukan menerapkan beberapa teknik yang dapat mengekspos modul olahan bonggol jagung, sehingga nantinya menghasilkan gagasan yang dapat dimanfaatkan, terutama dari segi unsur visual berupa pemanfaatan tekstur pada modul bonggol jagung, sehingga menjadi suatu kebaruan untuk rancangan produk fungsional. Adapun produk yang diusungkan untuk penggunaan material olahan bonggol jagung adalah tableware. Hasil dari penelitian ini adalah munculnya gagasan terkait pemanfaatan unsur visual berupa tekstur modul dengan penerapan teknik yang berbeda yang dapat menjadi kebaruan yang tepat untuk diterapkan pada perancangan tableware.
\end{abstract}

Kata Kunci- material olahan, bonggol jagung, tableware, tekstur

\begin{abstract}
Processed corn-con material has characteristics which is potential as non-conventional material applied in functional product design. This research has the purpose for knowing more potentials from the processed corn-cob and how is the implementation in the function of tableware product. The way to knowing the potentials is with doing some of technique which is expose the main visual of the texture of processed corncob, so the end result is the idea of utilize the texture of corncob with proper technique to create novelty in tableware desain. In this case, tableware is the product that will be applied with processed corn-cob material in its design. The final result of this research is obtained new ideas of utilizing the texture of corn-cob by applying proper technique, which is become a true novelty in tableware design.
\end{abstract}

Keywords—processed material, corn-cob, tableware, texture

\section{PENDAHULUAN}

Bonggol jagung diketahui sebagai tumbuhan berserat memiliki potensi karakteristik yang dapat digunakan sebagai material perancangan produk. Terlebih bonggol jagung sering ditemukan di berbagai tempat sebagai material., melihat potensi yang ada pada bonggol jagung sebagai material perancangan produk, peluang untuk munculnya kebaruan dan orisinalitas dalam desain akan muncul serta membuka wawasan terkait manfaat yang didapat jika dapat memanfaatkan potensi yang ada pada bonggol jagung, dan dapat menjadi alternatif pengganti bahan baku yang sudah ada seperti kayu, bambu, rotan, dan lain sebagainya apabila persediaan bahan baku tersebut habis [1], [2], [3], dan [4]. Sehubungan dengan hal tersebut maka, sebenarnya akan muncul potensi kebaruan pula dalam industri kreatif, khususnya desain produk dengan memanfaatkan unsur visual dari olahan material bonggol jagung, sekaligus mencoba potensi industri kreatif dalam pemanfaatan bahan non-konvensional untuk perancangan produk [5] dan [6]. Bonggol jagung selama ini diketahui berbentuk silinder, begitu juga berbagai olahan produk yang memanfaatkan karakteristik bentuk silinder dari bonggol jagung tersebut. Contoh industri kerajinan yang telah memanfaatkan modul bonggol jagung berbentuk silinder adalah sebuah sentra kerajinan di Bogor dibawah binaan saudara Eddie [7] dan [8], seprti dapat dilihat pada Gambar 1.

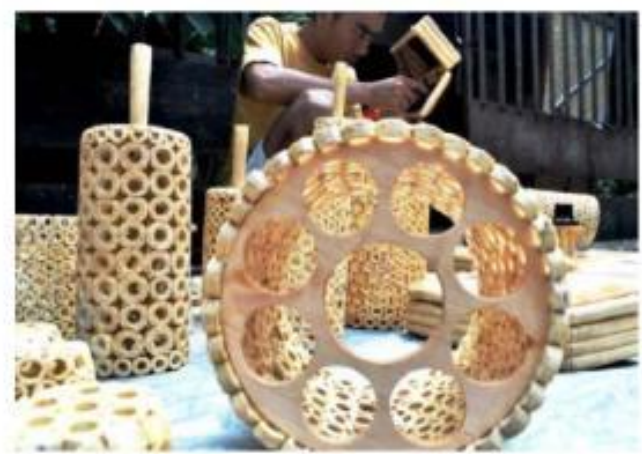

Gambar 1. Pembuatan produk dengan pemanfaatan olah bonggol jagung silinder (Sumber : pioneer.com)

Adapun pemanfaatan olahan bonggol jagung tersebut adalah untuk memanfaatkan karakteristik secara unsur visual dan kekuatan (kapasitas) dalam menahan beban.

Dalam kasus ini, bonggol jagung akan diolah di PT. Craftindo Kreasi menjadi berbentuk balok dengan ukuran yang berbeda-beda. Hal ini juga bertujuan untuk menciptakan kebaruan dalam ranah perancangan produk dengan material olah bonggol jagung berbentuk balok, yakni dimana bonggol jagung yang berbentuk silinder diproses 
melalui tahap penyerutan dan pengampelasan sehingga berbentuk balok (Gambar 2).
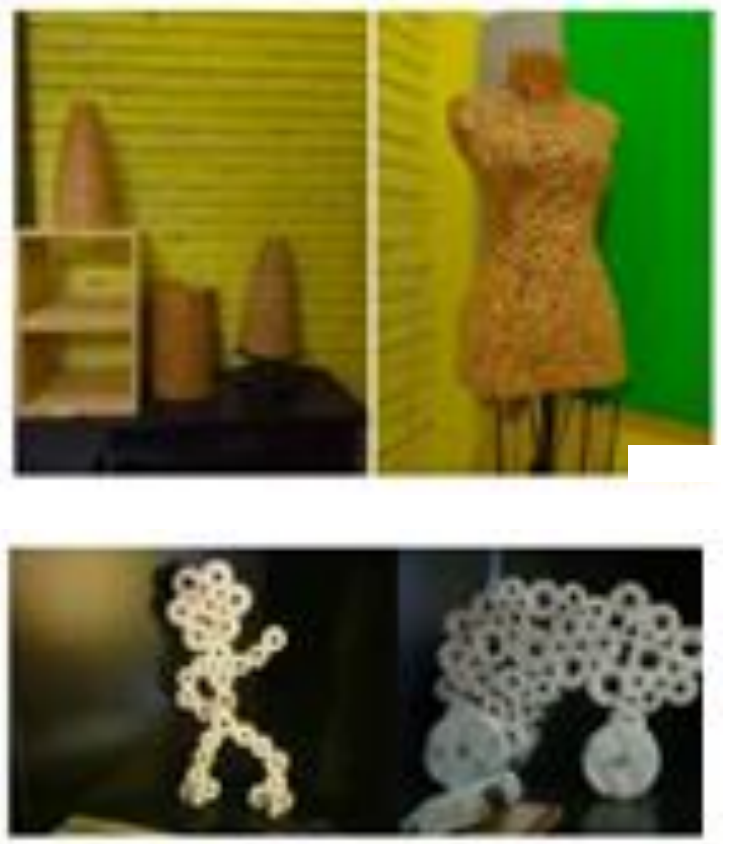

Gambar 2. Pembuatan produk dengan pemanfaatan olah bonggol jagung silinder di PT. Craftindo Kreasi (Sumber : Pribadi)

Terlebih, bahwa potensi yang terdapat pada olahan bonggol jagung pun dapat menjadi elemen estetis, yaitu :

1. Elemen interior; produk yang berfungsi sebagai nilai tambah keindahan pada interior, misalkan jam,figura, pajangan dinding, ataupun tableware pada meja makan

2. Produk Fashion

3. Produk Furniture

Adapun konsep produk yang akan diusulkan adalah tableware, yang selain menjadi produk yang biasa diletakkan di atas meja makan dan juga fungsional karena sering digunakan untuk aktivitas menyantap makanan, tableware juga dapat dijadikan sebagai unsur dekoratif di atas meja makan dan menambah elemen serta nilai estetis pada interior tempat diletakkannya meja makan tersebut.

\section{METODOLOGI}

Metode yang digunakan adalah eksplorasi bentuk yang akan dilakukan pada material olahan bonggol jagung berbentuk balok, yang meliputi uji karakteristik dan ketahanan modul terhadap suatu kondisi dan beban. Hasil dari metode yang dilakukan adalah hasil eksplorasi modul bonggol jagung balok yang berpotensi dijadikan konsep desain tableware.

Adapun kerangka berpikir dari konsep pembuatan tableware dari bonggol jagung dapat dilihat pada Gambar 3. Adapun metodologi yang akan diangkat di penelitian ini adalah proses Ideate/Brainstorming berdasarkan prinsip "Basic Process Design” yang dicetuskan oleh Tim Brown. Proses Ideate/Brainstorming ini diterapkan pada saat proses curah gagas pemanfaatan unsur visual tekstur bonggol jagung dengan penerapan teknik yang berbeda-beda sehingga menghasilkan teknik yang sesuai dengan perancangan tableware berbahan modul bonggol jagung tersebut.

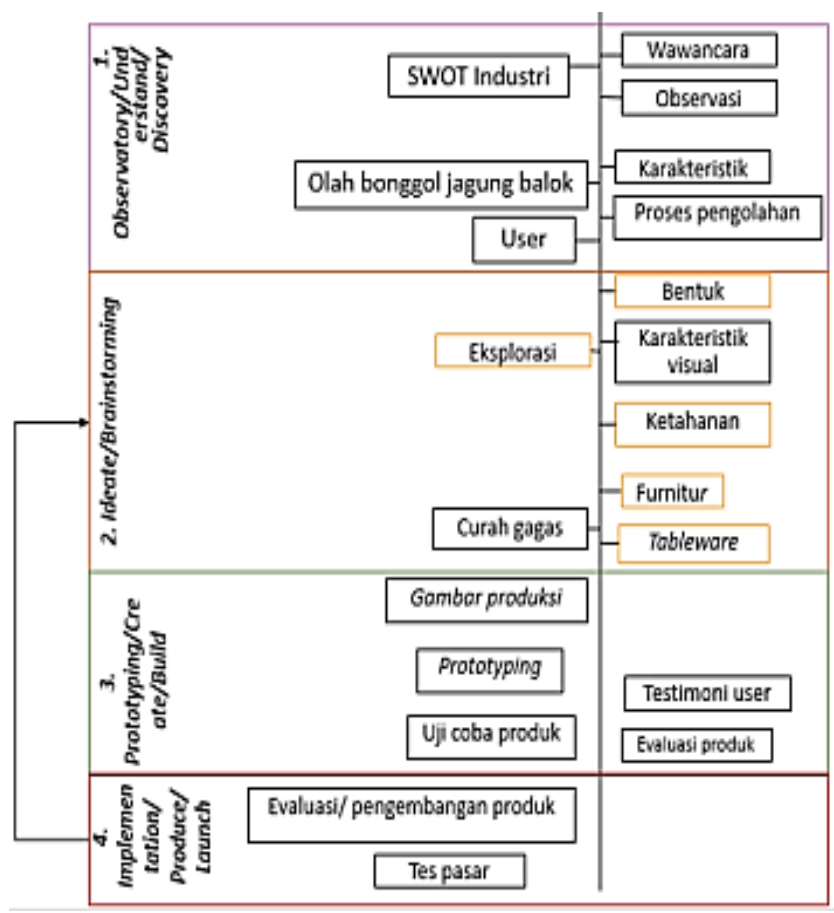

Gambar 3. Bagan proses penyelesaian desain "Basic Process Design" oleh Tim Brown.

\section{HASIL DAN PEMBAHASAN}

Adapun ukuran modul olahan bonggol jagung yang tersedia di PT. Craftindo Kreasi dapat dilihat pada Gambar 4.

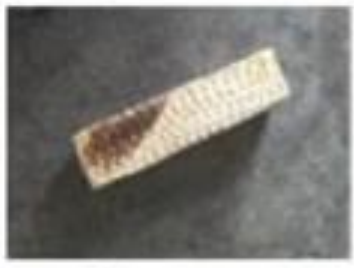

Pxixt : $7 \times 2 \times 2$

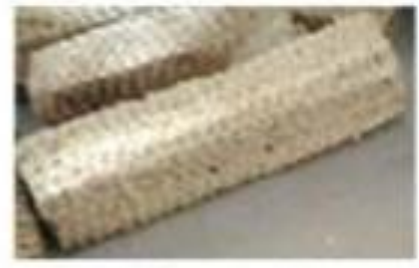

Pxlxt : $10 \times 2 \times 2$

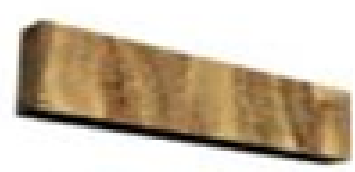

\section{Pxlxt : $10 \times 1 \times 2$}

Gambar 4. Berbagai ukuran modul bonggol jagung di PT. Craftindo Kreasi.

Selanjutnya, pengujian karakteristik modul olahan bonggol jagung dapat dijelaskan sebagai berikut :

\section{Penyusunan papan dari modul}

Papan disusun dari modul bonggol jagung berukuran $7 \times 2 \times 2 \mathrm{~cm}$ dengan cara menempel modul dengan lem kayu., dan akan diuji kekuatan dan kapasitasnya dalam menahan 
suatu beban sehingga nantinya akan diketahui kapasitasnya jika dimanfaatkan sebagai produk fungsional (Gambar 5).

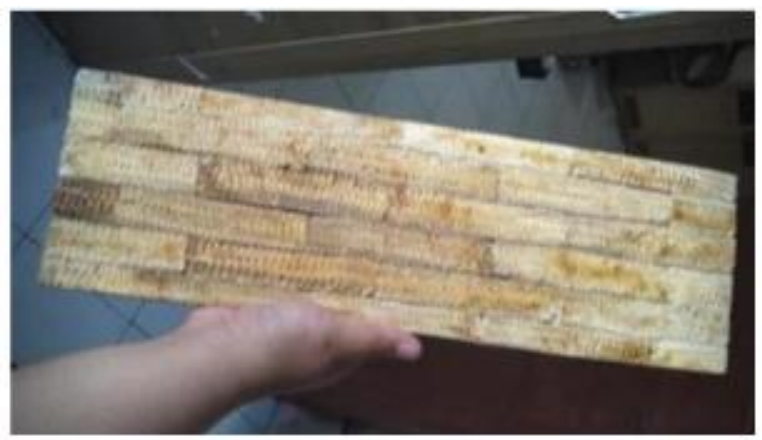

Gambar 5. Papan susunan modul bonggol jagung.

Kendala yang dihadapi saat penyusunan papan adalah pada saat terkena air, modul menjadi melengkung, tidak selurus ketika masih menjadi susunan papan, sehingga akan mengacaukan susunan papan itu sendiri jika tidak diberi lapisan anti air. Hal ini juga berlaku pada susunan modul dengan wujud bubut maupun bending.

\section{Pengujian kekuatan}

Kemudian, dilakukan uji coba ketahanan modul terhadap beban tertentu, yakni dengan studi kasus ukuran modul yang diterapkan sebagai dudukan stool dengan dimensi $60 \times 60 \times 2 \mathrm{~cm}$ (Gambar 6).
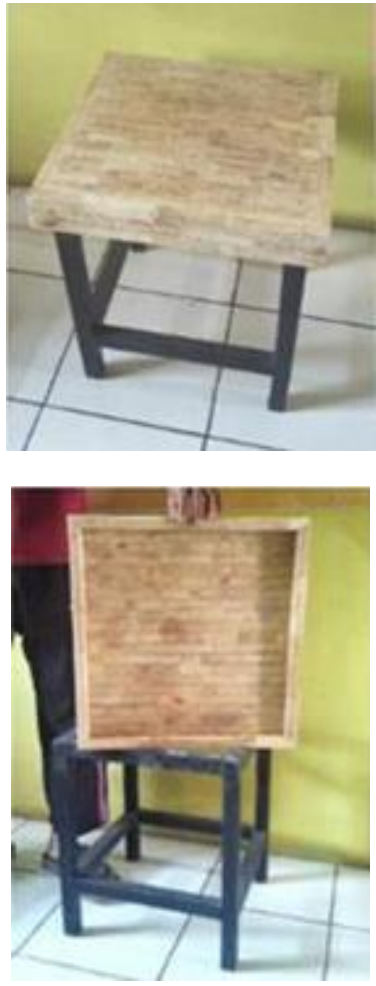

Gambar 6. Dudukan stool dari modul olahan bonggol jagung.

Adapun hasil yang didapat setelah melalui tahap pengujian kekuatan adalah, bahwa papan laminasi bonggol jagung berukuran $37,8 \times 10,6 \times 2$ kuat menahan beban $<40 \mathrm{~kg}$, sedangkan papan berukuran 60x60x2 yang ditumpuk dua kali kuat menahan beban hingga $70 \mathrm{~kg}$, jadi semakin banyak tumpukan pada papan laminasi bonggol jagung, semakin kuat papan tersebut menahan jumlah beban.

\section{Pembubutan}

Balok dibentuk dari susunan modul bonggol jagung yang kemudian dibubut. Adapun diameter bonggol jagung setelah dibubut adalah $8 \mathrm{~cm}$ (Gambar 7).
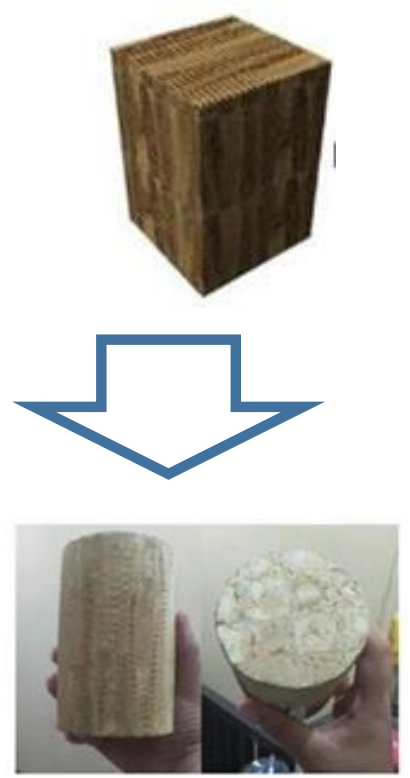

Gambar 7. Modul bonggol jagung yang dibubut.
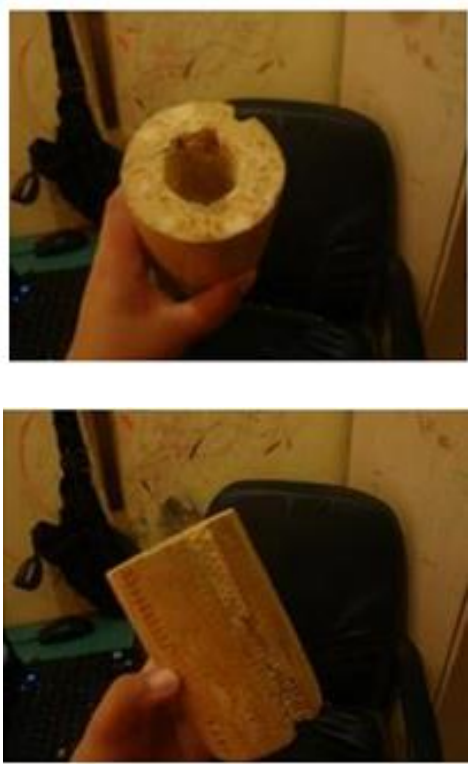

Gambar 8. Modul bonggol jagung yang dibubut pada bagian dalamnya.

Eksperimen lebih lanjut yaitu melakukan pembubutan bagian dalam, yaitu melubangi modul yang sebelumnya telah dibubut. Namun ternyata kedalaman yang diperoleh ketika melakukan bubut dalam pada modul terbatas, yaitu hanya menghasilkan diameter 3,5 cm dengan kedalaman 5,5 cm (Gambar 8).

Adapun tujuan pembubutan modul yaitu untuk mengetahui potensi lain dari visual karakteristik bonggol jagung serta 
mengetahui apakah nantinya modul tersebut akan bisa dimanfaatkan tak hanya dari segi visual, namun juga kekuatan ataupun struktur.

Pada saat melakukan pengujian modul dengan cara dibubut setelah menyusun satuan modul olahan bonggol jagung menjadi balok terlebih dahulu, ternyata hasil yang didapat dari teknik pembubutan adalah modul memiliki keterbatasan diameter dalam pembubutan, baik bubut luar maupun bubut dalam akibat sulitnya mesin serta besi pisau bubut untuk berkompromi dengan karakteristik modul olahan bonggol jagung yang memiliki kekerasan yang berbeda-beda, tidak seperti kayu yang memiliki kekerasan yang stabil dan merata, sehingga jika melakukan pembubutan dalam waktu lama untuk mencapai ukuran yang lebih dari batasan, akan menyebabkan rusaknya modul; seperti susunan modul yang terlepas, ataupun ketidakmampuan besi pisau bubut untuk membubut lebih lanjut.
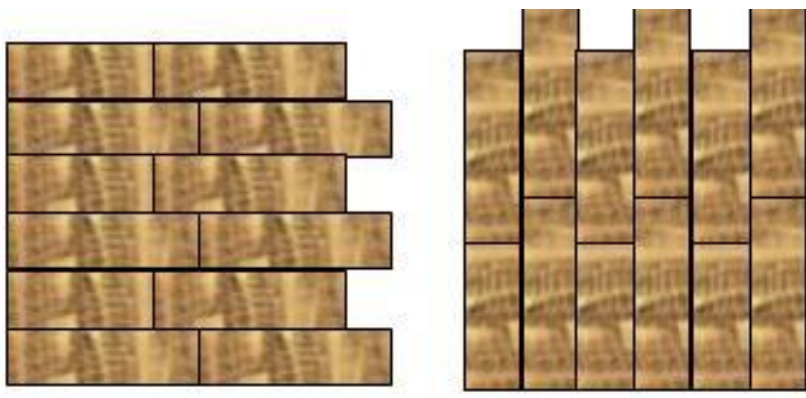

Gambar 9. Ilustrasi pola susunan bonggol jagung.

Adapun untuk batasan ukuran pembubutan luar pada balok modul olahan bonggol jagung adalah Sama dengan diameter ukuran semula, yaitu 2,5 cm (misal, diameter ukuran balok semula $8 \mathrm{~cm}$, ketika dibubut hanya dapat mencapai diameter $5,5 \mathrm{~cm}$ ). Kemudian batasan ukuran pembubutan dalam pada balok modul adalah diameter 3,5 cm dengan kedalaman 5,5 $\mathrm{cm}$. Meskipun untuk mencapai bentuk lingkaran, sebagai alternatif dapat menggunakan teknik mencetak papan susunan modul dengan mal berbentuk lingkaran untuk kemudian dipotong dan diampelas mengikuti bentuk mal.

\section{Teknik bending}

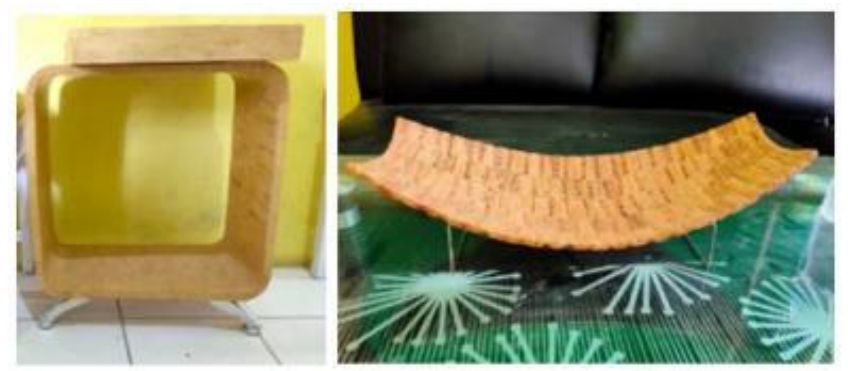

Gambar 10. Hasil dari penerapan teknik bending pada meja dan nampan yang terbuat dari papan susunan modul yang dilakukan di PT. Craftindo Kreasi.

Dilakukan pula ujicoba teknik bending pada papan yang terbuat dari susunan modul. Adapun pola susunan bonggol jagung disusun sebagaimana yang disertakan pada ilustrasi pada Gambar 9. Kemudian, untuk mencapai hasil dari teknik bending, dilakukan menggunakan bantuan pipa paralon, sehingga menghasikan bentuk seperti dapat dilihat pada Gambar 10

Adapun teknik bending mendapatkan bentuk ketika mengikuti alat cetak (contoh, paralon). Namun, sebelum melakukan bending, kumpulan modul direndam terlebih dahulu di dalam air selama 1-2 hari. Setelahnya, modul yang telah di lem diberi cetakan untuk proses bending, dan memakan waktu 4 hari sampai hasil bending terlihat

Adapun pola penyusunan diterapkan tergantung produk yang akan dibuat, berikut perbandingan ketika melakukan teknik bending dengan pola susun horizontal dan vertikal adalah sebagai berikut, dengan contoh kasus membuat meja seperti dapat dilihat pada Gambar 11
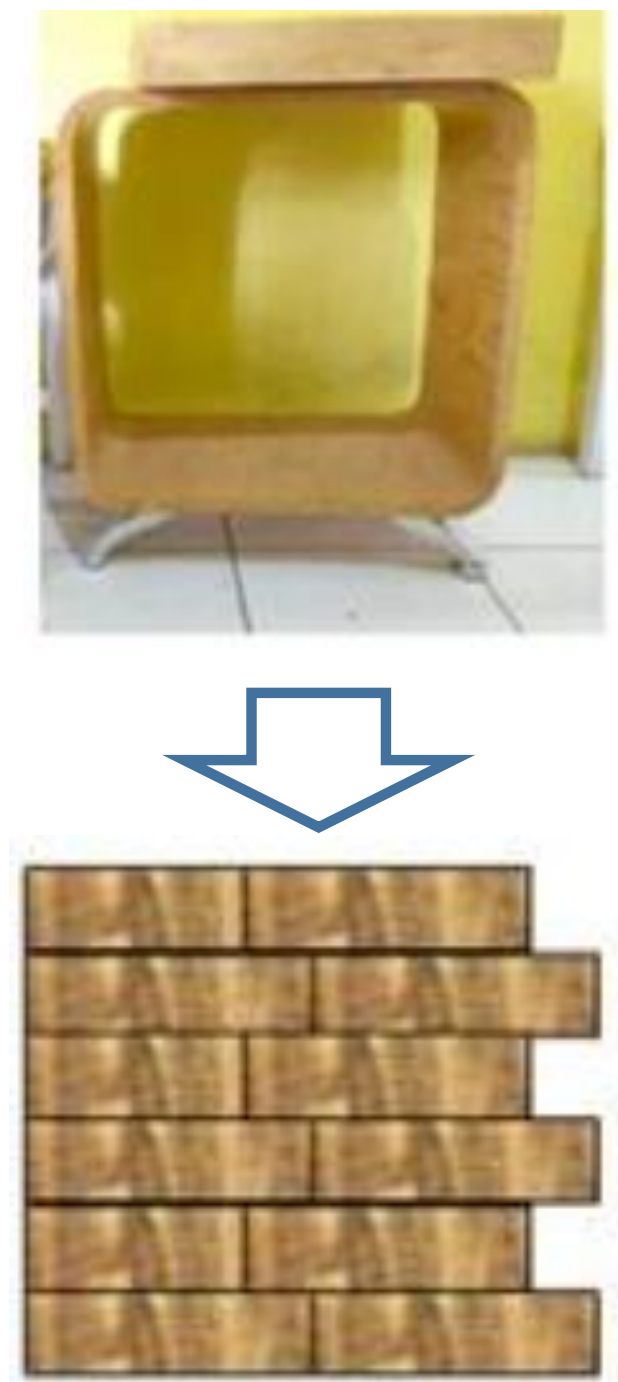

Gambar 11. Hasil dari penerapan teknik bending pada meja dan nampan yang terbuat dari papan susunan modul yang dilakukan di PT. Craftindo Kreasi.

Sedangkan pada pembuatan nampan buah, dilakukan proses bending dengan cara pemolaan, yaitu dimana satuan modul dibuat berbentuk pola satu-persatu, kemudian dibending, lalu disusun menjadi bentuk pola yang ditetapkan (Gambar $12)$. 

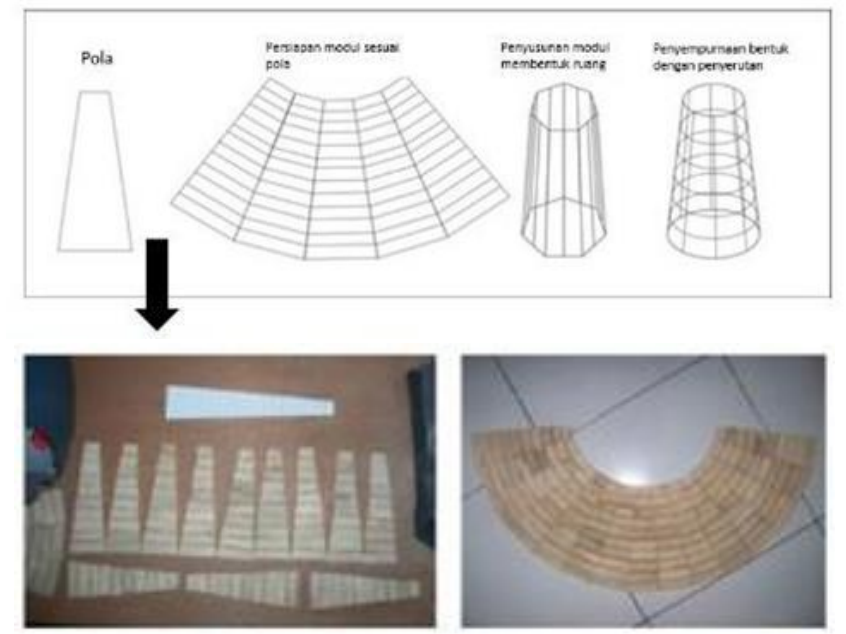

Gambar 12. Teknik pemolaan pada satuan modul bonggol jagung [5]

Tabel 1 menunjukkan perbandingan bending antara susunan modul dan satuan modul

Tabel 1. Perbandingan bending antara susunan modul dan satuan modul.

\begin{tabular}{|l|l|}
\hline \multicolumn{2}{|c|}{ Perbandingan } \\
\hline
\end{tabular}

\section{Pendekatan bentuk prototype}

Bentuk nampan ini menggunakan pendekatan teknik uji kekuatan, bending dan pencetakan bentuk menggunakan mal pada sisi nampan, serta teknik pembubutan sebagai kaki nampan (Gambar 13).

Adapun inspirasi bentuk pada desain tableware ini yang berasal dari burung gelatik dan daun jagung. Mengetahui bahwa burung gelatik memakan biji jagung, maka mendapat gagasan bentuk tableware mengikuti lekuk tubuh burung gelatik,ataupun bentuk lekuk daun jagung yang juga merupakan bentuk organik (Gambar 14).

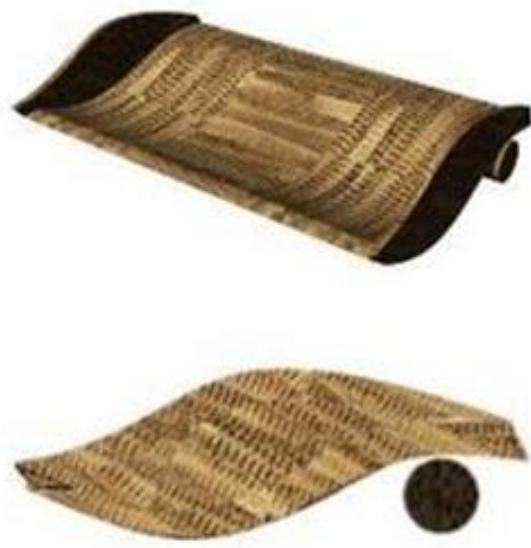

Gambar 13. Bentuk nampan yang memanfaatkan teknik bending.

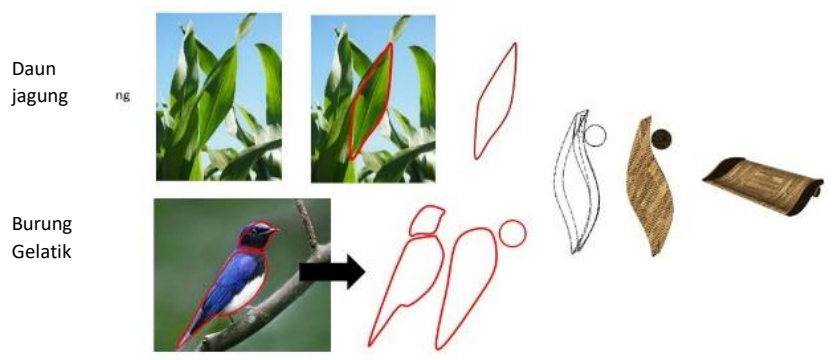

Gambar 14. Tahapan pembentukan desain dari inspirasi lekukan tubuh burung gelatik dan daun jagung.

Sedangkan proses pencarian bentuk dari prototype ini adalah dari eksperimen membuat bentuk lingkaran dari modul sebagai alas, dan penyusunan dengan menerapkan teknik cetak dan bending dengan pola vertikal, mengikuti bentuk saringan logam untuk tepung yang sudah ada (Gambargambar 15 dan 16).
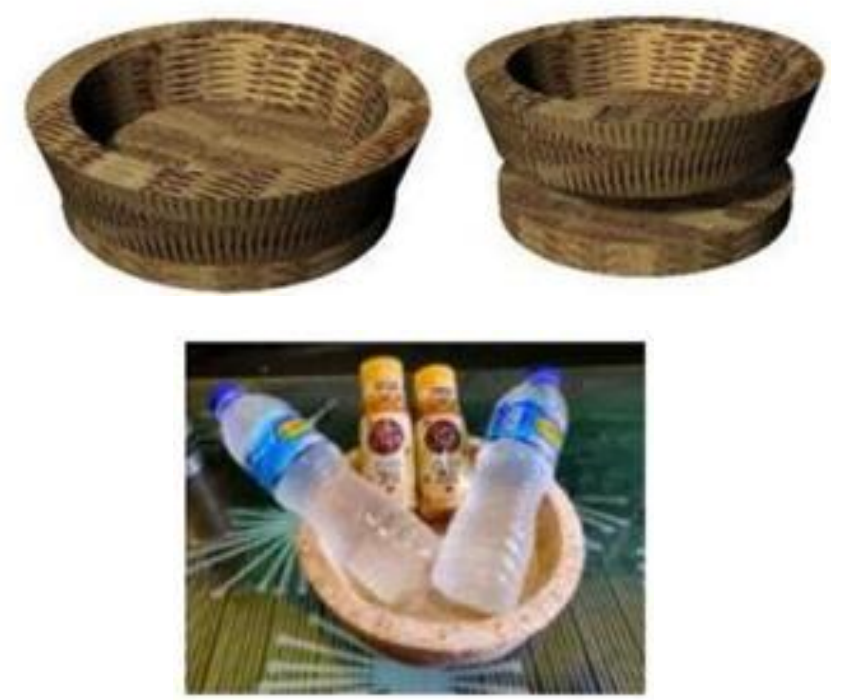

Gambar 15. Bentuk wadah roti yang memanfaatkan teknik bending vertikal. 

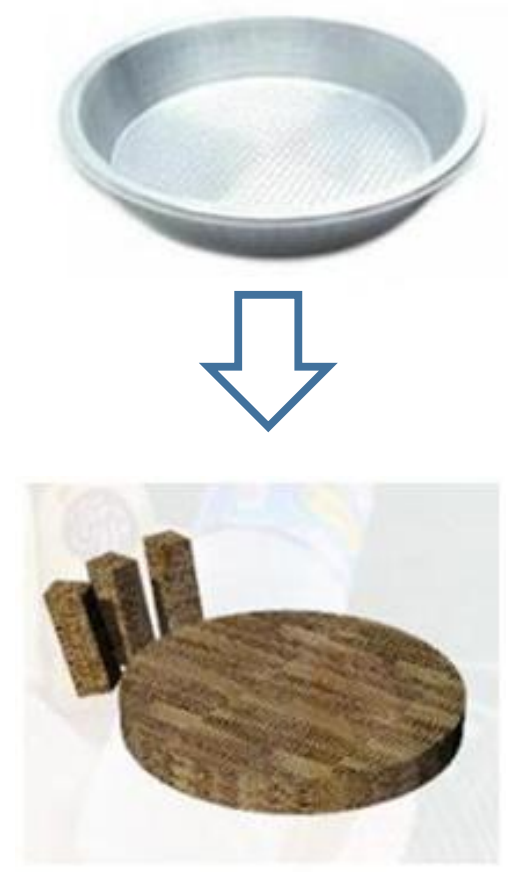

Namun, dengan keterbatasannya perlakuan untuk mencapai hasil unsur visual dari modul olahan bonggol jagung, dapat menjadi peluang untuk menciptakan kebaruan dalam perancangan produk dari olahan bonggol jagung tersebut, sehingga dihasilkan rancangan produk tableware berbahan dasar modul bonggol jagung berbentuk balok.

\section{DAFTAR PUSTAKA}

[1] N. Cross, "Engineering Design Methods, Strategies for product design", Second Edition (John Wiley \& Sons Ltd, Baffins Lane, Chichester, West Sussex, PO19, England, 1998)

[2] M. Ashby, K. Johnson, "Materials and design, the art and science of material selection in product design" (Butterworth Heinemann, Oxford, UK, 2007)

[3] H. Christians and A. Bremmer, "Applied ergonomics", 29, 3, 201-211 (1998)

[4] Masri, Andry. 2015. "Eksplorasi Material Bonggol Jagung untuk Mendapatkan Nilai Kebaruan.” Program Doktoral, Institut Teknologi Bandung, Bandung, Indonesia.

[5] Ismail, Dedy. 2011. "Eksplorasi material bonggol jagung untuk produk fungsional studi kasus wadah buah.” Jurnal Rekayasa Institut Teknologi Nasional 3.

Gambar 16. Proses penyusunan bentuk wadah roti yang memanfaatkan teknik cetak mal dan bending vertikal.

\section{KESIMPULAN}

Berdasarkan hasil uji coba yang dilakukan pada modul olahan bonggol jagung, ternyata modul olahan bonggol jagung dapat lebih diekspos secara unsur visual, namun memiliki perlakuan yang lebih terbatas untuk mencapai unsur visual tersebut ketimbang jika merancang suatu produk dengan unsur visual dari material seperti kayu, bambu, rotan, dlsb, seperti ditunjukkan contoh bahwa modul tidak bisa dibubut sebaik kayu.

[6] Ismail, Dedy. 2011. "Uji Fisik Bonggol Jagung Olahan sebagai Alternatif Bahan Baku dalam Konsep Produk Fungsional." Jurnal Rekayasa Institut Teknologi Nasional 3.

[7] Wahmuda, Faza. 2015. "Pengembangan Desain Produk dari Tongkol Jagung Berbasis Industri Kreatif." Seminar Nasional Sains dan Teknologi Terapan III Institut Adhi Tama Surabaya.

[8] Wahmuda, Faza, dan Anastasia Wangge. 2014. "Alternatif Desain Produk dari Sampah Tongkol Jagung Dilihat dari Jenis Tongkolnya (Dalam Upaya Pengendalian Pencemaran Lingkungan)." ITATS Seminar Nasional Sains dan Teknologi Terapan 7 